\title{
Poverty Alleviation through Corporate Social Responsibility in Niger Delta, Nigeria
}

\author{
Bede Obinna Amadi (Corresponding author) \\ Department of Social and Development Sciences, Faculty of Human Ecology \\ Putra University Malaysia, 43400 UPM Serdang, Selangor, Malaysia \\ E-mail: bedeamadi@gmail.com \\ Haslinda Abdullah \\ Department of Social and Development Sciences, Faculty of Human Ecology \\ Putra University Malaysia, 43400 UPM Serdang, Selangor, Malaysia \\ E-mail: lynn@putra.upm.edu.my
}

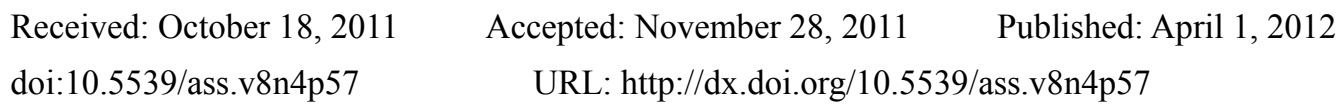

\begin{abstract}
Failed government's policies aimed at developing the Niger Delta region left it one of the poorest regions of Nigeria; and necessitated agitations by the communities for oil multinationals to step in to fill this development gap. Through the company's corporate social responsibility, Shell Petroleum Developing Company - the Nigerian subsidiary of Royal Dutch Shell has demonstrated commitments to the reduction of poverty in the region. The paper examines some of the company's poverty alleviation projects in the region. Using a qualitative approach, drawing on relevant secondary data and content analysis the paper argues that Shell has contributed immensely to the development of local communities in its areas of operation and also contributed to the economic growth of Nigeria. However, given the vast majority of the region's population living in poverty, the paper advises that government should complement the efforts of Shell both in the region and across the country using massive wealth generated for the government by the oil company.
\end{abstract}

Keywords: Corporate social responsibility, Poverty alleviation, Niger Delta, Shell petroleum developing company, Corruption

\section{Introduction}

Despite being rich in natural resources, the prevalence of poverty is very high in Nigeria, with over 70 percent of the population surviving on less than US\$1 per day, meaning that most Nigerians are living in excruciating poverty (Omideyi, 2009). This soaring incidence of poverty is in sharp contrast to the country's position as a prominent petroleum producing country in the continent. Over 90 percent of Nigeria's external revenues are derived from crude oil exports; yet this huge profit has yet to improve the deplorable human condition and misery index of the oil producing communities (Orogun, 2009). Idemudia (2007) argued that neglect of basic services in the Niger Delta in past years by successive Nigerian governments enshrined poverty in the region.

Over the years, Nigeria has adopted several poverty alleviation programmes, aimed at alleviating or eradicating poverty; yet, the nation's oil wealth has done little to improve the life of the poor population due to corruption, political instability, weak administration, poor macroeconomic management, and bad governance (Oshewolo, 2010). Consequently, poverty has remained a pervasive problem in the Nigerian society, and with a much more devastating dimension in the Niger Delta region where unemployment, underdevelopment and squalor are stacking realities of daily living for most of the people (Chukuezi, 2009). This development gap has led to the reliance on the oil multinational companies (MNCs) by their host communities to step in and fill this wide development gap. Despite their contribution to the development of society, governments at all levels in Nigeria and the political elites continue to apportion blame on the MNCs for the poverty situation in the region; with such culture of blame inciting the community members into believing that the MNCs are massively exploiting 
them, while giving too little or nothing in return to them in the form of development (Ite, 2005). This has occasioned community protests, agitations and conflicts in the region.

The paper critically evaluates corporate social responsibility (CSR) programmes of Shell Petroleum Developing Company (SPDC) aimed at developing local communities of the Niger Delta area of Nigeria. It argues that SPDC has contributed enormously to local community development as a way of addressing poverty, but their efforts are constrained by factors which are political and social.

\section{Theoretical framework}

The paper is guided by the triple bottom Line theory. The theory is most suitable to the paper, having been extensively used in several related studies. It illustrates the MNCs' involvement in community development as a responsibility to the community based on stakeholders' relationship that benefits host communities and business.

The quest for a tripartite win for the economy, society, and for the environment led to the development of the triple bottom line (Elkington, Emerson \& Beloe, 2006). The reason behind the triple bottom line paradigm is that a corporation's ultimate success should be measured not just by the traditional financial bottom line, but also by its social/ethical and environmental performance. This idea confirms the established fact that firms have a variety of obligations to stakeholders to be socially and ethically responsible. It was John Elkington, a US business strategist who coined the term, and having it widely accepted following publication of his 1998 book, Cannibals with Forks: The Triple Bottom Line of 21st Century Business (Elkington, 1998). Triple bottom line, abbreviated as "TBL" or "3BL", is becoming more prevalent across disciplines, mostly in management, consulting, investing, and NGO circles; and has been embraced by many eager to give social and environmental agendas more prominence in the face of globalization. The concept of triple bottom line has been embraced and promoted, and major corporations such as AT\&T, Dow Chemicals, Shell, and British Telecom, have used 3BL terminology in their press releases, annual reports and other documents; so have scores of smaller firms (Norman \& MacDonald, 2003).

The concept of TBL, also known as "people, planet, profit" or "the three pillars" requires that a company's business practices should be beneficial to stakeholders rather than shareholders. In this case, a stakeholder refers to anyone that is influenced by the actions of the firm, either directly or indirectly. And the business entity should be used as a vehicle for coordinating stakeholder interests, instead of maximizing shareholder (owner) profit. Illustrating further the concept of triple bottom line theory, the California Accountability Project (CAP, 2002) believes that an obligation to CSR presupposes a corporation's reformulation of its mission in terms of TBL, that is, financial, social and environment. And that together with the shareholders, the company has a plethora of stakeholders that are affected by the company's operations, including employees, investors, consumers and local communities; as such, TBL calls for effective policies, procedures, and systems that will enhance the company's accountability to stakeholders and the general public.

In the realm of community development, a commitment to TBL is a unique approach that addresses community challenges. Corporate social responsibility embodies the prospects of dealing with the host communities and consequently addressing the development challenges of the region. Placet, Roger, and Fowler (2005) contend that CSR would ensure sustainable development with its three main goals of environmental stewardship, social responsibility, and economic prosperity for everyone involved. And that environmental stewardship and social responsibility, when pursued, will boost realizing the third goal, economic prosperity for the company. Thus, the thrust of TBL notion is that companies operate ethically responsible to the society and the physical environment in which they operate (Eweje, 2006).

\section{Situating the Niger-Delta region, Nigeria}

The Niger Delta is defined both geographically and politically. The former comprises of states in the South-South geo-political zone, namely, Delta, Bayelsa, Rivers, Akwa Ibom and Cross River States; while the political Niger Delta extends to the neighboring oil producing states of Ondo, Abia and Imo, for reasons of administrative convenience, political expedience and development objectives (UNDP, 2006). It is an oil rich region; and the oil generating an estimated $\$ 600$ billion since the 1960 s for the government (Amnesty International, 2009). The current potentials of the region in terms of oil and gas deposits alone is estimated at about at 34 billion barrels and about 160 trillion cubic meters of gas reserves (Powell, Marriott \& Stockman, 2005). The Niger Delta is one of the most important wetlands and marine ecosystems in the world after the Mississippi and is the largest in Africa (Nseabasi, 2005). It consists of a number of ecological zones, which range from sandy coastal ridge barrier to low-land rainforest; teeming with bird, marine life, giant ferns and towering mangrove plants, the creeks and swamps. 
A major aspect of the region is its general state of underdevelopment, underemployment, extreme poverty, and lack of proper and adequate infrastructure. Failed and abandoned development projects, meant to improve the material living conditions of the people characterise the rural regions of the area, while economic and social rights, such as the right to an adequate standard of living, remain unfulfilled (Maxted, 2006). The United Nations Development Programme describes the region as suffering from "administrative neglect, crumbling social infrastructure and services, high unemployment, social deprivation, abject poverty, filth and squalor, and endemic conflict" (UNDP, 2006). The majority of the people of the region do not have adequate access to clean water or health-care. Their poverty and its contrast with the wealth generated by oil is a classic example of the paradox of poverty amidst plenty.

\section{Government's development efforts in the Niger Delta}

As stated earlier, various governments in Nigeria have initiated development programmes with a view to reducing poverty in the Niger-Delta region; unfortunately, the outcome has been appalling due to corruption, misapplication of development resources, and bad governance (Osuntokun, 2000). Some of these government agencies charged with alleviating poverty in the region include the Niger Delta Development Board (NDDB), the Niger Delta Basin Development Authority (NDBDA), the Oil Mineral Producing Areas Development Commission (OMPADEC), and the Niger Delta Development Commission (NDDC). The last two are examined in this paper, as they represent the most notable official responses to the development challenges of the area.

\subsection{Oil Mineral Producing Areas Development Commission}

OMPADEC was established in 1992 by the Federal Government in response to the need for the region to receive some developmental gains, and alleviate the social, economic and environmental problems caused by oil exploration (Okonta \& Douglas, 2001). Consequently, three percent of federal oil revenue was allocated to the Commission to address the development needs of the area. Despite its novel goals, and after raising the spirit and hopes of the people, the vast majority of the people did not benefit from its activities as most of its projects had little to do with poverty reduction. OMPADEC was criticized for its wastefulness, inefficiency, massive mismanagement and corruption. For instance, Sanya (2006, cited in Omotola, 2007) noted that OMPADEC embarked on projects worth $\$ 500$ million in its first three years of existence; but the bulk of money for supposed completed projects was paid out to contractors whose addresses could not be traced. Frynas, (2001) also noted that in September 1998, Eric Opia, the sole administrator of the institution was sacked for his inability to account for N6.7 billion, then worth US $\$ 80$ million.

Furthermore, the manner with which the agency was established and the political motives of its sponsors is believed to have contributed in jeopardizing its task of developing the Niger Delta. While Obi (2001) believes that the military regime at the time established OMPADEC as a public relations gesture to calm the brewing crisis in the area, Okonta and Douglas (2001) noted that several community leaders in the region dismissed the agency as another white elephant project establishment to lure them into a false sense of contentment, believing that something is being done to redress past wrongs.

When OMPADEC was scrapped in 1999, several abandoned or unfinished projects were left behind, and huge debts were owed. Among other things, it lacked a master plan where its objectives, focus and strategies should be defined. Azaiki (2003) argues that the commission lacked an integrated development plan that made provision for sustainable development programmes, project assessment, and long-term project planning that incorporated enforcement, monitoring, servicing, and maintenance mechanisms required to achieve its developmental goal. The Federal Government of Nigeria, in its Niger Delta Regional Development Master Plan 2001, also acknowledged that reliable information on the total amount the OMPADEC received from the federation account was never found; while at the same time admitting that the commission suffered from lack of focus, inadequate and irregular funding, official profligacy, corruption, excessive political interference, lack of transparency and accountability, and high overhead expenditure. Thus, the inefficiency and corruption led to the failure of OMPADEC as it failed to abate discontent and restiveness in the region.

\subsection{Niger Delta Development Corporation}

To address the wave of agitations and demands of the communities, the federal government in December 2000 set up the Niger Delta Development Commission (NDDC), with the mandate "to conceive, plan and implement projects and programmes for the sustainable development of the Niger Delta area and to undertake infrastructural development in the region" (NDDC, 2001). A further mandate of the commission included formulating and implementing programmes and a master plan aimed at promoting a rapid sustainable development and transformation of the Niger Delta region in such areas as education, employment, health, water supply, electricity, housing, transportation, telecommunication, urban development, agriculture, fisheries and industrialization 
(Azaiki, 2003).

As part of its vision to improve the lives of the people of the Niger Delta region, the NDDC designed a master plan, which not only aimed at the socio-economic development of the area, but also political and environmental development. The master plan comprised a chain of well defined development objectives, policy and project proposals and implementation guidelines, which are required to facilitate the region's growth and development. Five major components of the master plan include, environmental protection and sustainability, economic, community, institutional and infrastructural development. Curbing youth restiveness in the region and improving the living condition of were also planned by the commission, aimed at providing mass employment through the diversification of the region's economy (NDDC, 2004).

In over a decade of its existence, NDDC, no doubt, has recorded some progress, given the number of projects it has implemented in the region in various sectors; however, the commission has not fully lived up to expectations as evident in the poor infrastructure in the area. Omotola (2007) argues that some of the projects which the NDDC boasts to have commissioned and completed may be fictitious, exaggerated, or handled in manners inimical to the advancement of public interest. Part of the reasons for the ineffectiveness of the commission includes the structure of the organization, which not only limit and cripple the commission, but also hinders it from having accesses to both political and economic powers that should have facilitated the commission's objectives. The commission lacks the necessary powers to function efficiently. For instance, it is under the direction, control, and supervision of the president. And not only is it administered by the president, it has a status of an advisory kind that can only make policy proposals (NDDC Act, 2000).

Another factor that militates against the success of the NDDC is funding. The approved funding formula requires the federal government to contribute 15 percent of the 13 percent oil revenue allocations allocated to the nine states, while the oil companies contribute 3 percent of their annual budget. 50 percent of funds due to the member states from the ecological fund are also allocated to same NDDC fund. Unfortunately, there is evidence that the commission does not receive all the allocations as approved, which has made it difficult for it to transform the region (Akinwale \& Osabuohien, 2009). As such, little progress has been made in the area as evident in the continued dire condition of the people. Corroborating this stance, Saliu and Omotola (2007) maintain that the NDDC has not bequeathed significant improvement in the welfare of the Niger Delta people due to corruption, occasioned by the composition of the Commission, which allows for financial misappropriation; and feared that the condition of the region will continue to deteriorate if the situation continues unabated. The NDDC, as stated by Emmanuel, Olayiwola and Babatunde (2009) has not lived up to its mandate of providing sustainable development to the region, because poverty has continued to strike on the people of the area, while funds meant for the eradication of the region's poverty are embezzled by those at the affairs of the state.

\section{Understanding Corporate Social Responsibility}

Corporate social responsibility (CSR) as a concept is not new. Steiner and Steiner (2006) traced the concept to the philanthropic work of business owners, John D. Rockefeller and Andrew Carnegie, who offered millions of dollars to social causes. They argued that the concept of CSR was first introduced in 1954 in Howard R. Bowen's book entitled, Social Responsibilities of the Businessman; where the author stated that managers have an ethical duty to consider the wider social impacts of their decisions, and warned that the corporations that fail to encourage the broad social contract should cease to be regarded as being legitimate. There is no universally accepted single definition of CSR (Whitehouse, 2006). The concept is broad, and is split into various themes and sub concepts, as such being incorporated by various disciplines, ranging from public policy to environmental science, which has increased the body of literature and interpretations of the concept (Carroll, 1999). Although CSR, as aforementioned, was historically thought to concern only the idea of philanthropy, it is now established that CSR has developed into an umbrella term (Whitehouse, 2006). The term now encompasses such concepts as business ethics, corporate citizenship, corporate accountability, sustainability, socially responsible investing (Ingley, 2008), and corporate community involvement (Nwankwo, Phillips, \& Tracey, 2007; Seitanidi \& Ryan, 2007).

While Paul and Siegel (2006) define CSR as the advancement or promotion of some social good; Wood and Jones (1995) uphold that CSR is the duty for business to address social, environmental, and economic demands from stakeholders. The divergent views of the term, according to Masaka (2008) were in part due to varied social issues and societal expectations across international contexts. He however insisted that, despite the body of interpretations of the concept, a common feature across a number of definitions that scholars have proposed on the concept of CSR is the general belief that, beyond the quest to maximize corporate profits, corporate 
organizations play a crucial role in solving society's problems (Masaka, 2008). The notion of CSR, which used to be associated with corporate philanthropy, now comprises everything from charitable contributions and social investment to the direct integration of the vulnerable populations into a corporation's regular business practice (Gutierrez \& Jones, 2005). Worthy of note also is the fact that while some authors believe that CSR-based policies and programmes were initially employed by the companies in the mid-twentieth century to ward-off criticisms of their social and environment practices (Gutierrez \& Jones, 2005; Micklethwait \& Wooldridge, 2005), others argue that lots of organizations are adopting CSR as an approach to reduce the negative social and environmental impacts of business as well as to maximize the positive impacts of their investments, especially in developing countries (Blowfield, 2005; Zadek, 2001).

Against the backdrop of various definitions of CSR, and the several activities that the concept has been used to describe, it suffices to think of the concept as an umbrella term used to describe a variety of beliefs and practices (Blowfield \& Frynas, 2005). The rationale and assumptions behind the corporate social responsibility discourse can be summed up as follows: (1) corporations should think beyond making money and pay attention to social and environmental issues; (2) corporations should behave in an ethical manner and demonstrate the highest level of integrity and transparency in all their operations; (3) corporations should be involved with the community they operate in terms of enhancing social welfare and providing community support through philanthropy or other means (Banerjee, 2008). These views capture the quintessence of CSR as conceived by the advocates of the concept, which demands that corporations should play a vital role in solving society's problems. According to Lépineux (2005), such supposition is based on the notion that the interest of business and the rest of society are inextricably connected; and that corporate actions are required to support the economic and social wellbeing of the people who constitute society. It is imperative, therefore, to have a community-based approach to CSR in which corporations play an active role in initiating social policies and community development projects (Lertzman \& Vredenburg, 2005; Lund-Thomsen, 2005).

\section{Multinational Corporations and Corporate Social Responsibility}

The need for CSR is more prominent in the developing countries than in developed countries because development projects and other social infrastructure are lacking in most of these countries, and most of the time they are not provided by the government. Under these circumstances, MNCs tend to come under heightened requirements and expectations to fill those gaps (Baughn, Bodie, \& McIntosh, 2007). On their own part, the MNCs acknowledge that the support given to CSR in recent years has become a constant action in corporate environment - such that companies use various communication channels like their official websites, annual reports, or other promotional materials to promote the activities of CSR, in order to give credence to the fact that the community's life and sustaining social causes are part of the significant activities that they perform.

In China, for instance, multinationals have been supportive to their host communities in several ways, with a significant part of their poverty assistance being educational aid, which itself accounts for 30 percent of all social responsibility activities, as against environmental protection and disaster relief which account for approximately 20 percent each (Samsung Economic Research Institute, 2006). The CSR activities are aimed at improving the level of education in economically underdeveloped areas, so that residents will be able to equip themselves with improved conditions of living. For example, through their CSR, Coca cola has supported the Project Hope, which is a program to support youngsters in poverty-stricken areas around China since 1993, and has maintained a strong network of schools, ranging from primary schools to universities (Samsung Economic Research Institute, 2006). The educational aid, which later incorporated youth education and vocational training are geared towards raising the educational level of the communities in view of fostering local talents and increasing potential customer base.

Many researchers have acknowledged the importance of CSR for MNCs operating in developing countries, especially, the desire to attract foreign investment and jobs as a development strategy. The Global Environmental Management Initiative (GEMI, 1999) believes that developing countries recognize that MNCs investment not only provides imminent economic benefits, but also provides a crucial foundation for economic prosperity. The United Nations (1999) therefore enjoins the developing countries to achieve the necessary political and economic environment that attracts foreign direct investment (FDI); and stresses that countries lacking in FDI have economies that are heavily dependent on government regulations and controlled by inefficient state-operated monopolistic enterprises, with attendant incidences of extreme poverty, repressed human rights, and excessive environmental damage. Lodge (2006) observed that the MNCs involvement in CSR is crucial to global poverty reduction, especially in the developing countries, because poverty reduction requires systemic change, and MNCs are the world's most efficient and sustainable engines of change; offering opportunity for people who are convinced there is none; building roads and hospitals and other infrastructure. 
MNCs mostly get involved in CSR in countries where governments are negligent of their duties of raising the living standard of the people or lack the ability to do so. In such countries, even the financial assistance provided to such countries, and meant to help the neediest citizens most often aggravates their condition by sustaining the corruptions of such governments that contributed to their misery, by incurring huge debts for the states. In such inefficient countries, many multinationals, apart from making the profits upon which their survival depends, have often stepped in to address the people's needs. For instance, Nestlé and Unilever in India, Coca-Cola in Venezuela, Intel in Costa Rica, and Land O'Lakes International in Albania, just to mention but a few. Their initiatives not only provide jobs and raise incomes; they also improve education and give individuals motivation to pursue it (Lodge, 2006).

\section{The Case of Shell in the Niger Delta}

The Niger Delta is host to a list of oil multinationals such as SPDC, Chevron/Texaco, ExxonMobil, Total, Agip and their subsidiary contracting companies (Orogun, 2009). For the purpose of this paper, only the CSR programmes of SPDC in the Niger Delta are examined. SPDC is the pioneer multinational oil company in the Nigerian oil industry and has remained the biggest and leading oil company in Nigeria ever since. The company accounts for 40 percent of Nigeria's oil production, and 55 percent of the country's hydrocarbon reserve base. SPDC's business in Nigeria is centered in the Niger Delta, both onshore and adjoining shallow offshore areas where it operates in oil mining lease area of around 31,000 square kilometers. It has more than 6000 kilometers of pipelines and flow lines, 87 flow stations, 8 gas plants and more than 1000 producing wells. As a corporate citizen, Shell has for a long time been committed to the development of the communities in the Niger Delta. According to Ite (2005), Shell's initial form of community engagement dates back to the 1960 s when the company supported efforts aimed at improving the livelihood of the mostly rural communities of the region. Shell has continued to demonstrate commitment to CSR by been involved in programmes aimed at poverty alleviation in the Niger Delta. The company affirms that its operations strategy contributes to local development, first, 'through efficient and ethical standard of its business activities, in such a manner that is beneficial for both the host countries and communities; and the second is through investment that is far beyond philanthropic grants to actual technical and financial support for local development initiatives' (SPDC 2004).

\section{Findings}

This section evaluates the oil company's development interventions on poverty reduction in the Niger Delta. Some of the projects executed in the region are discussed under three subdivisions, namely, healthcare services, educational initiatives, and youth development initiatives.

\subsection{Healthcare Services}

In order to provide healthcare to their host communities, Shell has demonstrated concern for the health of the people of Niger Delta. This was inspired by the company's understanding that provision of qualitative healthcare cannot be a responsibility of government alone. Involvement in eradicating malaria is one of the ways the company's CSR is impacted in the host communities. Malaria increases the incidence of poverty as it affects the nation, community, family and individuals. The need for action on this preventable disease would no doubt reduce poverty and promote development. In achieving this, SPDC, in partnership with Africare initiated the Africare Malaria Health Integrated Project, designed to reduce childhood and maternal morbidity and mortality in the Niger Delta through malaria control initiatives (AFRICARE/SPDC, 2009). As declared by Dr Julius Coles, president of Africare, addressing the health needs of the people of the Niger Delta remains an underlying foundation for development of the region (Charity Wire, 2003).

Through the Malaria Health Integrated project of SPDC, Africare has, since 2003, been implementing the roll back malaria programme in 54 communities of the Niger Delta. In order to boost capacity in achieving the objective of this programme, the company provided capacity building training for some 1,074 public and private health care workers for malaria prevention and treatment; while forty seven non-government organizations (NGOs) and faith based organizations (FBOs) received grants to engage in malaria control programmes in the communities through awareness programmes, distribution of drugs and insect treated mosquito nets (SPDC, 2004).

Similarly, under the Niger Delta AIDS Response (NiDAR) project designed by SPDC, a selected list of hospitals across five member states of the region is providing high-quality HIV/AIDS services to the patients. To achieve this, SPDC works closely with communities, national and state agencies involved in the control of AIDS, Health Ministries at both the federal and state levels, and Family Health International (FHI) - an international NGO in the implementation of NiDAR. In partnership with FHI, SPDC completed in 2008 the \$2.2 million Niger Delta HIV/AIDS response project, with the company's share being $\$ 1.55$ million. This prototype scheme trained, in its 
first year, 2008, more than 240 healthcare providers, tested and counseled more than 4,000 people and treated more than 1,350 pregnant women to prevent mother-to-child transmission of the disease, and enrolled 730 people for HIV/AIDS treatment (SPDC, 2009). The project was to be managed from 2009 by the state-run HIV programme. It is worthy of note that 10 more hospitals were added to the NiDAR project in 2010, thanks to the success of the scheme, which is geared towards providing comprehensive HIV/AIDS care, treatment and services to more people in the region.

In order to bring healthcare closer to the people, Shell built three new community health care facilities in 2008; bringing the total number of Shell-supported healthcare facilities in the Niger Delta to 32. The facilities are staffed by more than 800 government-employed community health personnel. Some of the achievements of this gesture is that in 2008 alone the facilities treated more than 80,000 people, and helped to deliver more than 1,800 babies; while 40,000 people attended the health outreach programmes, which provided a range of services including health education, vaccinations, eye-testing, treatment of malaria and minor ailments, the distribution of mosquito bed nets, HIV screening and de-worming of more than 5,000 school children (Shell, 2009). In 2009 also, the facilities treated more than 265,000, helped to deliver more than 2,000 babies; and reached more than 114,000 through their health outreach programmes. In 2010, SPDC and the government of Rivers State commenced the first community-based health insurance program in Nigeria, involving the private sector, government and community, aimed at improving healthcare delivery in the communities (SPDC, 2011).

In the aspect of immunisation, SPDC partners with government in the delivery of routine immunisation through clinic based services in a certain group of supported health facilities as well as community based outreach activities. The company has a policy in their community health services policy to work as partners with host communities, government at all levels, local and international organizations, in order to improve the overall health of the host communities. One of the underlying principles for the company's interest in immunisation has been to impact on the vulnerable members of the community and those at risk, through health activities and programmes. And to make sure the goal of immunisation which ultimately is the eradication of polio is achieved, Fakunle (2010) stated that SPDC supported over 113 communities on immunisation services between 2004 and 2009; and provided logistics such as boats, land transport and stipends to immunisers during National Immunisation Days, reaching over 4.3 million children under five years old in the communities.

\subsection{Educational Initiatives}

SPDC is a major contributor to social investment; and educational initiatives are a critical part of their investment. The company's educational initiatives entail assisting host communities to provide sustainable and qualitative education that ultimately reaches all the people. It is the company's belief that education is a long-term investment with an equally long gestation period, and should be one of the best legacies to bequeath to individuals, groups and society. Against this background, SPDC, in partnership with NNPC, Total and Agip runs an annual scholarship programme, to support undergraduate students in Nigerian universities. The scholarship is of two categories, namely National Merit Award (NM) and Areas of Operation Merit Award (AOM). While the former is open to the larger Nigerian undergraduates, the later is exclusively for students from communities in which the SPDC operates. Similarly, the company runs another scholarship programme for the secondary schools across the states that constitute the Niger Delta. According to the company, the Secondary School Scholarship scheme is to help students pay through school, as well as enhance academic achievement in host communities.

As most rural schools in the oil producing areas have problems attracting teachers, the company sponsors teachers in 57 community schools. Eweje (2006) noted that educational programmes of Shell in the Niger Delta comprise not only the provision of teachers paid directly by the company and the building of classrooms, but also the payment of special rates to teachers to encourage them to go and teach in remote rural areas where governments are inactive. This is an expression of concern and commitment to the educational needs of their host communities.

\subsection{Youth Development Scheme}

Realizing that the youth are the hope of the future, SPDC made the reduction of unemployment among the youth a major priority for Shell Conglomerate in Nigeria, through their youth development initiatives. The Niger Delta youths, who have, over the time disrupted the oil business as an expression of their dissatisfaction, have gained real job opportunities through vocational training and job creation programmes, courtesy of Shell. The scheme, which is managed in partnership with local NGOs, has continued to offer skills acquisition training to the youths, such as in welding, sewing, auto mechanics, electrical work, computer technology, hairdressing, building, baking, soap making, plumbing and fitting. Shell stated that under the SPDC joint venture with other stakeholders, more 
than \$2.3 million was spent in 2009 to train 306 youths, in such skill areas as welding, pipefitting and carpentry, enterprise and leadership development, and conflict management. This was against the background that training can help young people acquire the skills they need in life.

Another way that SPDC has improved the lives of the youth is through their global LiveWIRE, which is a community investment programme that aims to help young people explore the option of starting their own business as a real and viable career option. In Nigeria, LiveWIRE programme, which is funded by SPDC and Shell International, seeks to add value to existing Shell's local policies and other initiatives providing support for the development of young people and their economic future. For example, the company's partnership with Nigerian telecom giant, Globacom, provides small-scale business management training, and assists people in setting up mobile phone enterprises. Since its inception, the LiveWIRE scheme has trained many Nigerian youths, including youths of the Niger Delta, giving them support to start their own small businesses. The ultimate aim of the scheme is to encourage and support youth development, specifically to help them become interested in setting up businesses and working for themselves.

Under the LiveWIRE project, SPDC is also partnering with USAID Nigeria and the International Institute of Tropical Agriculture (IITA) in an \$11.3 million project over five years to develop cassava farming. More than 3,400 farmers were trained in 2009 under this programme; 11,000 farmers received technical and business skills training; while 3,600 and 9,000 full-time and part-time jobs were created, respectively (SPDC, n.d.).

\section{Conclusion}

The failure of government to provide social infrastructure and development to her citizens necessitated the agitations for multinational oil companies to step in to fill this development gap. As one of the multinationals in the Niger Delta, Shell has always demonstrated social responsibility by providing projects aimed at poverty alleviation in the region. Government corruption has been a major barrier to turning oil revenues into benefits for the people of Nigeria, especially the oil producing communities. For instance, between 2006 and 2010, the joint venture operated by the SPDC contributed about $\$ 31$ billion to the government, while taxes and royalties to the tune of $\$ 3.8$ billion was paid by Shell Nigeria Exploration and Production Company (SNEPCo) over the same period (Shell, 2011). Again, the Shell operations in Nigeria contributed over \$161 million in 2010 to the Niger Delta Development Commission as required by law; while a further $\$ 71$ million was invested directly by SPDC and SNEPCo towards addressing the social and economic development challenges in the region (Shell, 2011). Therefore, one should have expected some glaring development achievement from government using such enormous wealth created by Shell. Yet, the multinationals have continued to show active commitments to their host communities by providing basic development projects. The company's contribution to poverty alleviation should be applauded. SPDC as a company does not have all the answers or the expertise to address the development challenges of the region, and cannot take the role of government in improving the rural communities. It is therefore recommended that government should complement their efforts by using the billions of dollars generated for the government by Shell to improve the lives of both the Niger Delta people and the entire nation.

\section{References}

AFRICARE/SPDC. (2009). Malaria/Health Integration Project (HIP): Report of the Final Evaluation. [Online] Available: http://www.africare.org/documents/HIP_FinalEvaluation2009.doc (May 16, 2011)

Akinwale, A.A. \& Osabuohien, E. (2009). Re-Engineering the NDDC's Master Plan: An Analytical Approach. Journal of Sustainable Development in Africa, 11(2), 142-159.

Amnesty International. (2009). Nigeria: Petroleum, Pollution and Poverty in the Niger Delta. London: Amnesty International Publications.

Azaiki, S. (2003). Inequities in Nigerian Politics: The Niger Delta, Resource Control, Underdevelopment and Youth Restiveness. Yenagoa: Treasure Books.

Banerjee, S.B. (2008). Corporate Social Responsibility: The Good, the Bad and the Ugly. Critical Sociology, 34(1), 51-79. http://dx.doi.org/10.1177/0896920507084623

Baughn, C.C., Bodie, N.L.D. \& McIntosh, J.C. (2007). Corporate Social and Environmental Responsibility in Asian Countries and other Geographical Regions. Corporate Social Responsibility and Environmental Management, 14(4), 189-205. http://dx.doi.org/10.1002/csr.160

Blowfield, M. \& Frynas, J.G. (2005). Setting New Agendas: Critical Perspectives on Corporate Social Responsibility in the Developing World. International Affairs, 81(3), 499-513. 
http://dx.doi.org/10.1111/j.1468-2346.2005.00465.x

Blowfield, M. (2005). Corporate Social Responsibility: Reinventing the meaning of Development. International Affairs, 81(3), 515-524. http://dx.doi.org/10.1111/j.1468-2346.2005.00466.x

California Accountability Project. (2002). Beyond Good Deeds: Case Studies and a New Policy Agenda for Corporate Accountability. Berkeley, CA: Author.

Carroll, A.B. (1999). Corporate Social Responsibility: Evolution of a definitional construct. Business and Society, 38(3), 268-295. http://dx.doi.org/10.1177/000765039903800303

Charity Wire. (2003). Shell and Africare form partnership to launch $\$ 4.5$ million health care programme in Nigeria. [Online] Available: http://www.charitywire.com/charity 1/04919.html (July 25, 2011)

Chukuezi, C.O. (2009). Poverty and Youth Restiveness in Nigeria: Implications for National Development. Ozean Journal of Social Sciences, 2(2), 97-103.

Elkington, J. (1998). Cannibals with Forks: The Triple Bottom Line of 21st Century Business. Stony Creek, CT: New Society Publishers.

Elkington, J., Emerson, J. \& Beloe, S. (2006). The value palette: A tool for full spectrum strategy. California Management Review, 48(2), 6-28.

Emmanuel, A.O., Olayiwola, J.J. \& Babatunde, A.W. (2009). Poverty, oil exploration and Niger Delta crisis: The response of the youth. African Journal of Political Science and International Relations, 3(5), 224-232.

Eweje, G. (2006). The Role of MNEs in Community Development Initiatives in Developing Countries: Corporate Social Responsibility at Work in Nigeria and South Africa. Journal of Business \& Society, 45(2), 93-129. http://dx.doi.org/10.1177/0007650305285394

Eweje, G. (2007). Multinational oil companies' CSR initiatives in Nigeria: The Skepticism of Stakeholders in Host Communities. Journal of Managerial Law, 49(5/6), 218-235. http://dx.doi.org/10.1108/03090550710841340

Fakunle, B. (2010). SPDC JV Renews N/Delta Health Commitment. [Online] Available: http://www.thisdaylive.com/articles/spdc-jv-renews-n-delta-health-commitment/81809/ (September 2, 2011)

Frynas, J.G. (2001). Corporate and State Responses to Anti-Oil Protests in the Niger Delta. African Affairs, 100(398), 27-54. http://dx.doi.org/10.1093/afraf/100.398.27

Global Environmental Management Initiative. (1999). Fostering Environmental Prosperity: Multinationals in Developing Countries. [Online] Available: http://www.gemi.org/resources/MNC_101.pdf (February 22, 2010)

Gutierrez, R. \& Jones, A. (2005). Effects of Corporate Social Responsibilities in Latin American Communities: A Comparison of Experiences. [Online] Available: http://www.csringreece.gr/files/research/CSR-1289998402.pdf?user=fd89c0d28a0bfe418704b52dfd21de73

(March 8, 2011).

Idemudia, U. (2007). Corporate Partnership and Community Development in the Nigerian Oil Industry: Strengths and Limitations. UNRISD Markets, Business and Regulation Paper 2. Geneva: United nations Research Institute for Social Development (UNRISD).

Ingley, C.B. (2008). Company growth and Board attitudes to Corporate Social Responsibility. International Journal of Business Governance and Ethics, 4(1), 17-39. http://dx.doi.org/10.1504/IJBGE.2008.017889

Ite, U.E. (2005). Poverty Reduction in Resource-Rich Developing Countries: What Have Multinational Corporations Got to do with it? Journal of International Development, 17(7), 913-929. http://dx.doi.org/10.1002/jid.1177

Lépineux, F. (2005). Stakeholder theory, Society and Social Cohesion. Corporate Governance, 5(2), 99-110. http://dx.doi.org/10.1108/14720700510562640

Lertzman, D.A. \& Vredenburg, H. (2005). Indigenous Peoples, Resource Extraction and Sustainable Development: An Ethical Approach. Journal of Business Ethics, 56(3), 239-254. http://dx.doi.org/10.1007/s10551-004-3528-8

Lodge, G.C. (2006). Multinational Corporations: A Key to Global Poverty Reduction - Part I. [Online] Available: http://yaleglobal.yale.edu/content/multinational-corporations-key-global-poverty-reduction- $\% \mathrm{E} 2 \% 80 \% 93$-part-i (August 23, 2010)

Lund-Thomsen, P. (2005). Corporate accountability in South Africa: The role of community mobilization in environmental governance. International Affairs Journal, 81(3), 619-633. 
http://dx.doi.org/10.1111/j.1468-2346.2005.00472.x

Masaka, D. (2008). Why enforcing corporate social responsibility (CSR) is morally questionable. Journal of Business Ethics and Organization Studies, 13(1), 13-21.

Maxted, J. (2006). Exploitation of Energy Resources in Africa and the Consequences for Minority Rights. Journal of Developing Societies, 22(1), 29-37. http://dx.doi.org/10.1177/0169796X06062967

Micklethwait, J. \& Wooldridge, A. (2005). The Company. New York: The Modern Library.

Niger Delta Development Commission. (2000). Niger Delta Regional Development Commission Act 2000. [Online] Available: http://www.nddc.gov.ng/the\%20NDDC\%20ACT.pdf (April, 19, 2010)

Niger Delta Development Commission. (2001). Niger Delta Regional Development Master Plan. [Online] Available: http://nddc.gov.ng/NDRMP\%20Chapter\%202.pdf (April 19, 2010)

Niger Delta Development Commission. (2004). Niger Delta Regional Development Master Plan: Draft 3. Directorate of Planning. Port Harcourt: Author.

Norman, W. \& MacDonald, C. (2003). Getting to the Bottom of "Triple Bottom Line". [Online] Available: http://www.uvm.edu/giee/EarthInc/resources/Criticism.pdf (July 15, 2010)

Nseabasi, A. (2005). Conflicts in Nigeria's Niger-Delta: Issues on Response and Management. International Journal of Social Sciences, 4(1), 161-175.

Nwankwo, E., Phillips, N. \& Tracey, P. (2007). Social investment through community enterprise: The case of multinational corporations' involvement in the development of Nigerian water resources. Journal of Business Ethics, 73(1), 91-102. http://dx.doi.org/10.1007/s10551-006-9200-8

Obi, C.I. (2001). The Changing Forms of Identity Politics in Nigeria under Economic Adjustment: The Case of the Oil Minorities Movement of the Niger Delta. Uppsala: Nordiska Afrikainstitutet.

Okonta, I. \& Douglas, O. (2001). Where Vultures Feast-Shell, Human Rights, and Oil in the Niger Delta. New York: Sierra Club Books.

Omideyi, A.K. (2009). Poverty and Development in Nigeria: Trailing the MDGS. African Networks on Ethnomedicine, 1(1), 3-17.

Omotola, J.S. (2007). From OMPADEC to NDDC: An Assessment of State Responses to Environmental Insecurity in the Niger Delta, Nigeria. Africa Today, 54 (1), 73-89. http://dx.doi.org/10.2979/AFT.2007.54.1.72

Orogun, P.S. (2009). Resource Control, Revenue Allocation and Petroleum Politics in Nigeria: The Niger Delta Question. GeoJournal, 75, 459-507. http://dx.doi.org/10.1007/s10708-009-9320-7

Oshewolo, S. (2010). Galloping Poverty in Nigeria: An Appraisal of the Government's Interventionist Policies. Journal of Sustainable Development in Africa, 12(6), 264-274.

Osuntokun, A. (2000). The Niger Delta and Nigeria's environmental problems. In Osuntokun, A. (ed.), Environmental Problems of the Niger Delta (pp.1-8). Lagos: Friedrich Ebert Foundation,

Paul, C.J.M. \& Siegel, D.S. (2006). Corporate Social Responsibility and Economic Performance. Journal of Productivity Analysis, 26(3), 207-211. http://dx.doi.org/10.1007/s11123-006-0016-4

Placet, M., Anderson, R. \& Fowler, K.M. (2005). Strategies for Sustainability. Research Technology Management, 48(5), 32-41.

Powell, A., Marriott, J. \& Stockman, L. (2005). The Next Gulf: London Washington and the Oil Conflict in Nigeria. London: Constable and Robinson Ltd.

Saliu, H.A. \& Omotola, J.S. (2007). The National Political Reform Conference and the Future of Nigerian Democracy. In Saliu, A.H. et al. (eds.). Perspectives on Nation Building and Development in Nigeria. Lagos: Concept Publications.

Samsung Economic Research Institute. (2006). Multinational Corporations in China and their Corporate Social Responsibility Practices. [Online] Available: http://www.seriworld.org/index.html (June 30, 2010).

Seitanidi, M.M. \& Ryan, A. (2007). A critical review of forms of corporate community involvement: from philanthropy to partnerships. International Journal of Nonprofit and Voluntary Sector Marketing, 12(3), 247-267. http://dx.doi.org/10.1002/nvsm.306

Shell Petroleum Development Company (n.d.) Health Care. [Online] Available: http://www.shell.com.ng/home/content/nga/environment_society/shell_in_the_society/health/basic_health_care/ 
(July 8, 2011)

Shell Petroleum Development Company. (2004). The New Approach: Sustainable Community Development. Lagos: SPDC.

Shell Petroleum Development Company. (2009). The Niger Delta AIDS Response (NiDAR) project. [Online] Available:

http://www.shell.com.ng/home/content/nga/environment_society/shell_in_the_society/health/hiv_aids/ (July 8, 2011)

Shell Petroleum Development Company. (2011). Improving Lives in the Niger Delta. [Online] Available: http://www-static.shell.com/static/nga/downloads/pdfs/briefing_notes/improving_lives.pdf (September 6, 2011)

Shell Petroleum Development Company. (n.d.). Empowering Niger Delta Youths. [Online] Available $\mathrm{http} / / / \mathrm{www}$. shell.com.ng/home/content/nga/environment_society/shell_in_the_society/youth_development/youth _development_scheme/(July 15, 2011)

Shell Petroleum Development Company. (n.d.). LiveWire Programme. [Online] Available: $\mathrm{http} / / / \mathrm{www}$. shell.com.ng/home/content/nga/environment_society/shell_in_the_society/business_development/liv ewire/achievements.html (September 22, 2011)

Steiner, G.A. \& Steiner, J.F. (2006). Business, Government and Society: A Managerial Perspective (11th ed.). New York: McGraw-Hill.

United Nations Development Programme. (2006). Human Development Report. Lagos: Author.

United Nations. (1999). World Investment Report 1999: Foreign Direct Investment and the Challenge of Development. United Nations Conference on Trade and Development. New York: United Nations.

Whitehouse, L. (2006). Corporate social responsibility: Views from the frontline. Journal of Business Ethics, 63(3), 279-296. http://dx.doi.org/10.1007/s10551-005-3243-0

Zadek, S. (2001). Third Generation Corporate Citizenship: Public Policy and Business in Society. London: The Foreign Policy Centre. 